\title{
THE NEED FOR VIGILANCE IN BANKING TRANSACTIONS IN THE LIGHT OF PREVALENT FRAUD, MISREPRESENTATION AND PONZI SCHEMES IN THE BUSINESS WORLD
}

\author{
The Trustees of the Insolvent Estate of \\ Grahame Ernest John Whitehead v \\ Dumas Case 323/12 [2013] ZASCA \\ 19 Unreported (20 March 2013)
}

\section{Introduction}

Numerous persons are inclined to take a risk by making short-term investments that promise substantial profit returns within the shortest possible time. In this respect people take a gamble and try their luck at whatever opportunity that presents itself. With this growing trend has also arisen fraudsters, whose business is to prey on possible investors by making investments in non-existent business ventures, and large numbers of "investors" have lost vast amounts of money in these get-rich quick schemes. One such example is found in the recent SCA decision of The Trustees of the Insolvent Estate of Grahame Ernest John Whitehead $v$ Dumas (The Trustees of the Insolvent Estate of Grahame Ernest John Whitehead $v$ Dumas GNP (unreported) 2013-03-20 Case no 323/12). The case involved a specialist medical practitioner, Dumas, who made an investment into a fraudulent scheme, having been misled through a misrepresentation by an agent of Whitehead, mastermind behind the fraudulent Ponzi scheme. As a result thereof, Dumas lost a couple of million Rands into the insolvent estate of Whitehead. As illustrated by this case note and the age-old adage that says "a fool and his money are soon parted", unwary persons could easily lose their hard-earned money. Hence, this case note seeks to enlighten would-be investors of the pitfalls of Ponzi schemes, such as huge financial loss as was experienced by Dumas, and encourage vigilance in making financial transactions. This it does through a critical examination of the Dumas judgment. It especially concerns the legal principles pertaining to monies that are transferred from one bank account to another bank account owing to fraudulent misrepresentation. Primarily, the case note takes a critical view of the manner in which the court applied these legal principles. While the court, in the authors' view, properly set out the legal framework, which is sound and correct, it nevertheless went wrong in its application of the law.

Therefore, the authors contend that, judged from these very legal principles that the court set out, it nevertheless came to an incorrect conclusion. If left unchallenged, the effect of the judgment will be to set a precedent inappropriately and wrongly that could amount to an unwarranted curtailment of legal protection afforded to persons who are induced by fraud 
and misrepresentation to transfer money into other people's bank accounts. In this case note the authors examine the canards of the judges' reasoning leading up to their decision.

As a starting point we examine the factual background of the case, then we move on to the critique and we conclude with the advice.

\section{$2 \quad$ Factual background}

The case of The Trustees of the Insolvent Estate of Grahame Ernest John Whitehead $v$ Dumas (supra) was an appeal to the SCA against an order of the North Gauteng High Court which had ruled that the plaintiff, Dumas (defendant in the present case), was entitled to a restitution of money transferred into Whitehead's bank account, owing to the fraudulent misrepresentation of Whitehead's agent. The appellants were the trustees of insolvent estate of Whitehead. Whitehead operated a fraudulent investment scheme in which investors were enticed to make short-term investments with a promise of huge profit in returns. The Pyramid scheme involved new investors making investments for fictitious transactions purportedly undertaken by the Salvation Army in the United Kingdom (par [3]). From new "investment" inflows, the old investors were then paid their "profit" returns (par [3]). When cash inflows from new investors dwindled, it inadvertently meant that there was no money to pay "returns" to old investors. Hence, many lost their money "so-invested". Dumas was one of those misled into believing that Whitehead's scheme was legitimate, through representations made by an agent acting on Whitehead's behalf. The agent made Dumas believe that his investment would generate a return of a third of his investment within a year (par [4]). On 28 April 2009, Dumas instructed his Bank, First National Bank (FNB), to transfer an amount R3 million into Whitehead's Absa Bank account. According to Dumas, he understood from the agent that the money would remain his property until he concluded a contract with Whitehead a few days later (par [4]). However, unbeknown to both the agent and Dumas, Whitehead had been under arrest in the United Kingdom for his fraudulent activities. He was afterward convicted and sentenced. Consequently, the planned meeting between Whitehead and Dumas to finalize the detail of the investment agreement did not materialize. As a result of his dealings and subsequent arrest, Whitehead's assets were frozen and his estates, both in South Africa and the United Kingdom, sequestrated.

Upon hearing of Whitehead's arrest, on 28 April 2009 Dumas instructed his bank, First National Bank (FNB), to reverse the transfer to Whitehead's account. Thereupon, FNB wrote to Absa requesting that the account into which the money had been deposited be put on "hold". Subsequently, no transactions were made from this account thereafter (par [5]). On 7 May 2009 , an urgent court order was granted for the provisional sequestration of Whitehead's estate. The court also ordered that the funds in two of Whitehead's accounts that he held with Absa bank be transferred to the trust account of Attorneys Coetzee Inc (par [7]). Following this order, an amount of R8 236605.54 was withdrawn from the two Whitehead accounts held by Absa and was paid into the Coetzee Inc trust account, pending the appointment of trustees to the sequestrated estate (par [7]). On 20 May 
2009, the Master of the High Court appointed the provisional trustees of Whitehead's insolvent estate. Thereafter, on 25 May 2009, Coetzee Inc paid the total amount of R8 236605 . 54 over to the trust account operated by the trustees. Meanwhile, on 26 May 2009 Dumas instituted a vindicatory application in the North Gauteng High Court for the return of his money.

\section{Proceedings High Court}

Dumas lodged a vindicatory claim (rei vindicatio) in the High Court Absa bank. His action before the High Court was based on his alleged ownership of the funds deposited into Whitehead's account. However, it appears that on the advice of his lawyers, Dumas realized that when it was deposited into any bank account money became the property of the bank. Thus the common-law remedy of rei vindicatio was therefore not available to Dumas, as by law it was available only to an owner seeking to recover his property. Hence, his vindicatory claiming could not succeed. Dumas then filed a supplementary replying affidavit in which he altered the legal basis of his claim from rei vindicatio to enrichment - the condictio ob turpem vel iniustam causam. Enrichment is a remedy available to a plaintiff who innocently transfers money to a defendant under an agreement, which, to the knowledge of the defendant, is illegal (par [10]). In this case the enrichment claim was sought to be enforced against Absa even though it was not party to the agreement between Dumas and Whitehead (par [10]). Dumas's claim was founded on the basis that, since the money was obtained from him fraudulently, it could therefore not form part of Whitehead's insolvent estate (par [2]). The high court, per Makgoba J, upheld Dumas's claim. It held that Whitehead could have no entitlement to the money (and thus could also have no claim against Absa) since Dumas had been induced to transfer the money into Whitehead's bank account through fraud and theft perpetrated on him by Whitehead (par [2]). The High Court concluded, therefore, that the money fell outside the estate of Whitehead and was not subject to the concursus creditorum (par [2]. (The concursus creditorium speaks of the concurrence of the rights and privileges of creditors; in this case Absa as the banker would not be entitled to the rights and privileges to which Whitehead as creditor of the bank would be entitled.) The bank therefore, the court reasoned, would have been enriched if it were to keep the money. Thus the bank had to repay the amount to Dumas. However, the trustees of Whitehead's insolvent estate appealed the matter to the SCA with the leave of the court.

\section{Proceedings in the Supreme Court of Appeal}

The Supreme Court of Appeal, per Cachalia JA (Lewis, Ponnan, Theron and Petse JJA concurring) held that once money was transferred into a bank account of another person, the transferor's personal right to the credit in the account was terminated (par [23]). Instead, the money became the property of the bank by the operation of the commixtio rule, regardless of whom made the deposit and the circumstances in which has been made (par [13]; also confirmed in Barnard Jacobs Mellet Securities (Pty) Ltd v Matuson 2005 CLR 1 (W) par [12]; and First National Bank of Southern Africa Ltd v Perry NO 2001 (3) SA 960 (SCA) 967H-I). (The commixtio rule is a law of property 
principle which means that once two or more objects of a nature similar to money are mixed together, they become a composite unit. With money for example, the money transferred into an account with other money loses its separate identity, and commixtio is one of the modes of acquiring property in goods. See also Schulze "Electronic Fund Transfers and the Bank's Right to Reverse a Credit Transfer: One Small Step for Banking Law, One Huge Leap for Banks" 200719 SA Merc LJ 379.) A new personal right is subsequently created in favour of the holder of the account into which the money has been transferred (see Van Jaarsveld "Aspects of Money Laundering in South Africa" published PhD 2011 University of South Africa, 134). Effectively this would mean that the bank becomes accountable to its customer (the holder of the account in which the money was transferred). The transferor, Dumas, therefore had no claim to the money as a personal right to the money that had been transferred to Whitehead (par [11]).) Therefore the money, according to the court, now fell into the insolvent estate of Whitehead (par [11]). For this reason, Dumas could not claim restitution of the money from the bank. The court pointed out that the only remedy available to Dumas, in the circumstances, was a claim for delictual damages against the insolvent estate of Whitehead (par [11]). The SCA thus disagreed with the judgment of the High Court and upheld the appeal with costs and set aside the order of the court a quo.

\section{Comments}

First, the court began by outlining the common-law principles governing banking in South Africa - the chain of rights and obligations that flowed when money was transferred from one bank account to the other. From the flow of rights as outlined in the judgment, the SCA then came to its conclusion that a personal right had been created in favour of Whitehead (see par [14], [15] and [16]). This, according to the court, then gave the insolvent estate of Whitehead a claim on the money in his account, albeit fraudulently obtained from Dumas. The finding of the SCA was founded on two main pillars. First, it was based on the principles governing banking transactions, as have just been explained herein. Secondly, the rationale for the court's finding was based on the partially correct view that Dumas intended to pay Whitehead and that he had voluntarily made the payment into Whitehead's account. Accordingly, to the court, it was immaterial that the payment was solicited through Whitehead's misrepresentation and fraud (see par [14], [15] and [16]). The court emphatically held that the transaction between Dumas and Whitehead, though tainted by fraud, constituted the causa for the payment nevertheless (par [23]). Hence, the trustees of Whitehead's estate could legitimately and lawfully claim the money from the bank, according to the reasoning of the court. We submit that this is not necessarily true. Instead, such reasoning on the court's part was mistaken and it was flawed for several reasons. Firstly, contrary to the SCA's latter argument, there was no justus causa for the payment of money from Dumas account to Whitehead's bank account or his insolvent estate. As agreed between Dumas and Whitehead's agent, the circumstances in which the money was transferred into Whitehead's account were such that the contract would only be concluded when Dumas and Whitehead met to finalize the deal. This was the only agreement that existed regarding the transaction that 
was made by Dumas. According to uncontroverted evidence, Dumas was in terms of this agreement misled to believe that the money he transferred remained his property until the envisaged contract between him and Whitehead was concluded. Effectively, there was no valid contract between Dumas and Whitehead that would have justified the passing of ownership of the money from Dumas to the insolvent estate of Whitehead. This agreed meeting between Dumas and Whitehead never materialized. The court failed to take cognisance of these factors. Therefore we submit that the reasoning of the court was incorrect as regarding the existence of a valid causa for the transaction.

Second, in the case of fraud and misrepresentation, the question was whether the transferor would have a personal right to claim return of his money from the fraudster's bank account with the receiving bank. As the SCA held, the money by law became the property of the recipient bank, which in turn became accountable to the holder of the account (and by extension, his insolvent estate) unless there was fraud (par [14]). In this case it was fraud and misrepresentation that had been responsible for inducing Dumas to transfer his money into Whitehead's bank account. The fact that ownership of the money was transferred to the bank upon transfer of funds was an ex lege function of banking law, instead of that a valid contract between Whitehead and Dumas (which we submit did not exist). Therefore, as a fraudster, Whitehead had no legitimate claim to the money. It followed also that his insolvent estate could not by law be entitled to the transfer of that amount into its account. In other words, one's estate cannot have more rights than what the owner has. Therefore, the fraudster, Whitehead had no legitimate claim to the money. Instead, the recipient bank owed a person in Dumas's position a duty to refund him his money.

Moreover, the SCA based its findings on the case of Nedbank $v$ Pestana (2009 (2) SA 189 (SCA)). Nedbank v Pestana (supra) involved a bank making a transfer of funds and unilaterally reversing the transaction. The court held in obiter that a resultant payment or bank transfer was treated as provisional (or conditional), and it was subject to a hold period in terms of "standard banking practice". See also Burg Trailers SA (Pty) Ltd v ABSA Bank Ltd (2004 (1) SA 284 (SCA) par [9]), where the court held that a cheque, for instance, had a 10-day holding period during which payment might not be made and the credit might be reversed). As such, it might be validly reversed where, among others, a cheque had been wrongly deposited into a client's account, or where the money came to the bank's client by way of fraud or theft. In the Nedbank case, the SCA used as authority the case of Nissan South Africa (Pty) Ltd v Marnitz NO (Stand 186 Aeroport (Pty) Ltd Intervening) (2005 (1) SA 441 (SCA)), together with a situation where a wrong account was erroneously credited. However, the court in Nedbank $v$ Pestana (supra) came to a different conclusion that the bank should not reverse the credit. Instead, it allowed the holder of the account in which the money had been deposited to keep the money. On the agreed facts and documentation before the court, there was no suggestion that either Pestana or the payee was a party to a theft or a fraud nor was there any other improper conduct relating to the money deposited into Pestana's account. Neither was there anything from the facts suggesting that the transfer of the money into the plaintiff's account was in any way 
conditional. Instead, there was a valid and lawful mandate from the bank's client, Pestana, to transfer money from his account to that of the plaintiff. Thus a legitimate transfer had occurred. This, of course, was a decision solely based on the case submitted before the court. Schulze is of the view that, rightly so in our view, it was clear that the court SCA in Pestana was faced with a case of fraud, but the way the case had been presented before the court tied the hands of the court to decide on the potential fraud, hence its decision that the credit should not be reversed (see Schulze "Electronic Fund Transfers and the Bank's Right to Reverse a Credit Transfer: One Big Step (Backwards) for Banking Law, One Huge Leap (Forward) for Potential Fraud: Pestana v Nedbank (Act One, Scene Two)" 200820 SA Merc LJ 290 295). He rightly stated that "one cannot leave unchallenged the decision by the Court that an electronic transfer is unconditional and that it cannot be reversed by a bank should it become aware that the recipient of the money was not entitled to it" (Schulze 200820 SA Merc LJ 296). Other instances where a bank could lawfully reverse a credit are, inter alia, when the money was transferred to the wrong person; where the wrong amount had been transferred; where the right amount was transferred to the right person but on the wrong date; and where the right amount was transferred to the right person on the right day (as what happened in Pestana), but the bank was not entitled to effect the transfer (because the s 99 notice by SARS had already reached Nedbank at the time when it transferred the money) (Schulze 200820 SA Merc LJ 296-297). The trite condition is that any reversal by the bank ought to take place within a reasonable period of time after the transfer has been made, and what is reasonable is to be determined on a sui generis basis (Schulze 200719 SA Merc LJ 387).

We are inclined to agree with Schulze (2008 20 SA Merc LJ 297) that "notwithstanding its findings regarding the so-called 'unconditionality of electronic transfers', the decision in the Pestana appeal contains no general principle regarding the 'unconditionality' of credit transfers". Effectively, then, even though the debit and credit transactions constitute a completed juristic act independent of any underlying justa causa, as the court a quo in Nedbank remarked, what follows after that recording of transactions is not absolute as there are exceptions when the bank may lawfully reverse the transactions. This would be the case, for example, where there had been fraud or an improper conduct by any one of the two parties involved (see, eg, Absa Bank Ltd v Standard Bank of SA Ltd 1998 (1) SA 242 (SCA) Par [252]). Hence, the transferee does not always have absolute personal rights to claim from the bank. The conditions that prevailed in Nedbank $v$ Pestana, although a different conclusion was reached regarding the reversibility of a credit by a bank, should firmly help Dumas's cause. The transfer transactions were induced by fraud on the part of Whitehead, Absa's client, while there was no improper conduct on the part of the FNB's client, Dumas. It is public policy that a bank should do all in its power to prevent or expose fraud, and it is unacceptable for a bank to turn a blind eye to the proceedings where fraud is apparent (Schulze 200820 SA Merc LJ 297). In support of this assertion, the court a quo in Pestana referred with approval to the SCA decision in Standard Bank of South Africa $v$ Oneanate Investments (In Liquidation) (1998 (1) SA 811 (SCA) 823), wherein Zulman JA noted thus 
"[e]ntries on bank accounts may reflect valid juristic acts, but that is not necessarily so. Whilst in general it may be said that that entries in a bank's books constitute prima facie evidence of the transactions so recorded, this does not mean that in a particular case one is precluded, unless say by estoppel, from looking behind such entries to discover what the true state of affairs is. So, for example, if a customer deposits a cheque into its bank account, the bank would upon receiving the deposit pass a credit entry to that customer's account. If it is established that the drawer's signature has been forged it cannot be suggested that the bank would be precluded from reversing the credit entry previously made".

As Schulze (2007 19 SA Merc LJ 382) noted of this statement by the SCA, applied to the facts in Pestana, it meant that Nedbank could not be precluded from looking behind the true state of affairs, that is, the erroneous transaction, and from reversing a credit entry previously made in the account of the plaintiff.

In spite of the knowledge of the circumstances outlined by the court where a bank was obliged to reverse a credit in the account-holder's bank account, the SCA in Dumas had dogmatically fixed its attention on the fact that once a debit and credit have occurred the completed transaction could not be reversed (see par [14]). It was for this erroneous stance that the court ignored key factors and concluded that Whitehead had acquired a personal right and that no reversal was permissible. We submit that in light of the present circumstances, there was no justification for the SCA to depart from this established position of law. As things appear, this irreversibility had no authority in law. It is submitted that the court erred when it allowed for a personal right to be created in favour of a fraudster (Whitehead) and subsequently his insolvent estate. From the SCA's own analysis of the law, transactions may lawfully be reversed by the bank on the basis of fraud and misrepresentation. That Absa put Whitehead's account on hold when requested to do so by FNB is testimony to the principle that the personal rights that the transferee's bank acquired were not absolute and that the bank could withhold or reverse a transaction where it was lawfully justified to do so (par [5]). Therefore, the Dumas case was wrongly decided on the facts. As the SCA judgment presently stands, the law has allowed for a creation of a personal right in favour of the fraudster through a deposit made into his account, although he had no entitlement to it. Neither Whitehead nor his estate could lawfully claim a right to the money by mere reason of the transfer, with complete disregard for the manner in which the transfer was induced.

In addition to the above, in Nissan South Africa (Pty) Ltd $v$ Marnitz (Stand 186 Aeroport (Pty) Ltd Intervening) (supra), a case that was applied in the court a quo and considered in the appeal, Streicher JA dismissed the liquidator's submission that once a bank unconditionally credited a customer's account with an amount received, the bank ought to pay on demand the money to the customer even if the money had been received through fraud or theft. Thus, the SCA in this case reversed the decision in Lombard Insurance Ltd v Firstrand Bank Ltd ((09/35913) [2011] ZAGPJHC 211 (8 February 2011)) which supported the view that a credit to a customer's account was unconditional regardless of how that money was obtained. The Nissan SA case involved money transferred from Nissan's account into a wrong account. The payee's estate was liquidated shortly 
after withdrawing the money, fully aware that it had been deposited as a result of a mistake. Nissan then applied to the court for an order declaring that what was left in the payee's account did not form part of the insolvent's estate. The SCA held there that, if stolen money was paid into a bank account to the credit of a thief, the thief had no legitimate claim to the credit representing the money so paid into the bank account. Hence, the court held that Nissan was entitled to claim from the account holder that money which he had already withdrawn whilst aware that the money did not belong to him, as well as a concurrent claim for the account balance against the bank holding the wrongly credited account. The court was of the view that withdrawing money from one's account while knowing fully well that it did not belong to one was tantamount to theft (see Van der Westhuizen and Duvenhage "The Legal Effect of Theft on Electronic Transfers in Modern Society: An Australian and South African Perspective" July 2013 3(4) World Journal of Social Sciences 56 66) who argued that this could not be termed "theft" as this did not infringe on either ownership or possession of the incorporeal credit transfer, but that it should rightly be termed "fraud". Therefore the insolvent estate of the payee and its liquidators were held not to have any claim to the money that was left in the payee's account. We submit that this same argument applied mutatis mutandis in respect of Whitehead and, by extension, his insolvent estate. Hence, the SCA's proposition that the ratio in Nissan did not apply in Dumas's case because the facts were different - in that Nissan dealt with an account holder who knowingly withdrew money that was mistakenly deposited into his account whereas Dumas dealt with stolen money falling into the account holders estate - had neither legal nor factual basis. It is non sequitur to conclude that because facts were different, the ratio decidendi will not apply in deciding another case. Inasmuch as the two factual scenarios differ, the same legal principles clearly apply. Both Nissan SA and Dumas dealt with a similar issue of account holders who sought to benefit unlawfully from funds that were not legitimately theirs. It is therefore submitted that as in Nissan, Whitehead clearly had no legitimate claim to the money because of the illegal way through which he obtained it. While the two cases differ slightly on facts, theft is a common denominator in respect of both (the only slight difference is that Dumas was misled by fraud and misrepresentation). We submit that the two cases ought to have been disposed of in the same manner.

Moreover, in relation to the aforegoing, a fundamental principle in law is that no one should be allowed to benefit from their own wrongdoing (Brooks $v$ Minister of Safety and Security 2009 (2) SA 94 (SCA) par [16]). This principle permeates through our legal system as a whole - from property law to succession and to delict law. Contract law should also be no exception and indeed it is not an exception. This principle is premised on the boni mores of society. It is submitted that the boni mores criterion is a fundamental standard that should inform the interpretation and the application of the law in any matter (not just constitutional and human rights cases) before a court. It is disturbing that at no point did the SCA refer to this principle, although the case at hand is clearly one of having a fraudster's estate benefit from his wrongdoing. At no point did the court make any reference to the legal convictions of the societal principle or policy considerations. It is submitted that this fundamental legal principle was violated by allowing the 
money illegally obtained by Whitehead to form part of his sequestrated estate. Inadvertently, this judgment of the SCA can rightly be construed as protecting the benefits of Whitehead's fraud. No legal convictions of the society, in the circumstances of Dumas case, would permit a court to order a release funds fraudulently acquired, into the insolvent estate of the account holder. The court has a moral and a legal duty to protect the interests of innocent victims of fraud and make restoration of whatever a victim would have lost without a just cause. In this case, it is submitted, the SCA failed to apply the law properly. Instead, it allowed a fraudster to create an advantage for his estate through fraudulent activities. Further, banks are not only accountable to their clients. They are also obliged to uphold the rule of law. It was thus an error on part of the SCA to allow a bank to release funds that were obtained by means of fraud into the fraudster's estate, instead of ordering the bank to reverse the transaction. As this judgment stands, it amounts to licencing banks improperly to facilitate fraudulent activities. The law cannot allow banks to facilitate fraudulent transactions. If the law were to do this this, it will be licensing banks to be accomplices in crime. It also amounts to an arbitrary deprivation of property, contrary to the constitutional guarantee of the right to property (s 25 of the Constitution, 1996).

The judgment is also flawed for another reason. It is significant that the investment agreement between Dumas and Whitehead had not been concluded. Dumas had effected the transfer in anticipation of a meeting with Whitehead where an investment contract was to be concluded. This meeting never materialized, for reasons explained to the court. Hence, we submit that this strengthens the argument that there was no justa causa for the transfer of the money into Whitehead's account. The SCA should have taken cognisance of this vital factor. It is submitted that Dumas has a claim against the bank for the restitution of his money on the basis that Whitehead had no personal right entitlement to the funds as he obtained them through unlawful means. The bank would thus be obliged to return the money to him as keeping that money without a corresponding obligation to release the money to Whitehead would amount to unjustified enrichment of the part of the bank. Thus, save for the law on the transfer of ownership and creation of personal rights when money in transferred from one bank account to another, there is no other sound legal reason for the SCA order that the money fraudulently transferred into the fraudster's bank account should reside in his sequestrated estate. There is therefore no rationale in proceeding to release these funds to the insolvent estate when the insolvent had no legitimate claim to the money.

The SCA held in an obiter comment that delictual damages should be claimed from the estate as the remedy instead of restitution from the bank (par [24]). However, it is submitted that delictual damages should be an additional remedy over and above the restitution of the money, albeit directed to the insolvent estate and not the bank. For this delictual claim, loss would include loss of investment earnings (positive interest) and any profitable use of the money. On the other hand, the question of fraudulent misrepresentation that would result in delictual claims being the only remedy, as the court suggested, will arise where a valid contract existed between the parties involved. As has been noted earlier, it is incorrect for the court to conclude that there was a contract between Dumas and Whitehead. 
There was no valid causa for the transfer of the money and no rights and entitlements passed from Dumas to Whitehead on the basis of a contract. We submit therefore that should delictual damages be raised as a remedy, it should be on the basis of a valid contract that had not been acted upon, not mere fraudulent deprivation of Dumas money. Hence, in the circumstances of the present case, Dumas would have been entitled to sue for loss of profits that would have accrued had the money been invested elsewhere not on the basis of misrepresentation as though a valid contract existed. Furthermore, a claim for delictual damages on the basis of loss of earning/profits (positive interest) is also available as a remedy by virtue of him being unable to invest his money elsewhere.

Although the court spelt out the remedy to be a delictual action against the insolvent estate, in light of the outcome of this case, it may be difficult for the victim of fraud to claim his or her amount in full, given that the estate of Whitehead is insolvent and is plagued with numerous debts due to the nature of his business. Further, without there having been a valid contract giving rise to clear obligations, the burden placed upon Dumas to raise a delictual action against the insolvent estate successfully and recovering all his money is quite onerous. In the present circumstances, Whitehead and his insolvent estate would have had no personal right to the money that Dumas deposited into his bank account. The Absa bank would therefore have had no obligation to pay Whitehead or his insolvent estate. However, as the court already had ordered Absa bank to release the money held in Whitehead's account into Whitehead's insolvent estate and the law, as decided by the SCA, has allowed the transfer into Whitehead's account to stand, Dumas can no longer proceed to claim against the estate on the basis of theft, as was the case in Nissan. It is therefore submitted that Dumas's claim now lies against the insolvent estate of Whitehead. Dumas has a legitimate claim for unjustified enrichment against the insolvent estate, to the amount that the estate was unjustly enriched. In this case the estate was unjustly enriched with the R3 million that he transferred to Whitehead's bank account; thus he would be entitled to claim this entire amount. There was no valid contract between Whitehead and Dumas - nor was there a iusta causa for the transfer. Accordingly, Whitehead's insolvent estate has not been unjustifiably enriched by receiving monies, which Whitehead nor the estate has legitimate right to receive. In such circumstances, the common-law remedy of unjustified enrichment has always been the legal remedy. The enrichment action in this case is the condictio ob turpem vel iniustam causam. According to Lombard Insurance Company Ltd v Firstrand Bank Ltd (supra par [10]), the general requirements for any claim based on enrichment are that "the defendant or respondent must be enriched, the plaintiff or applicant must be impoverished, the enrichment of the defendant or respondent must be at the expense of the plaintiff or applicant, and the enrichment must be unjustified or sine causa" (also McCarthy Retail Ltd $v$ Shortdistance Carriers CC 2001 (3) SA 482 par [15] and [20]; and Watson NO v Shaw NO 2008 (1) SA 350 (C) par [11]). As per Lombard Insurance Company Ltd $v$ Firstrand Bank Ltd (supra par [10]), the distinctive rules applying to the condictio ob turpem vel iniustam causam are that the ownership of the property must have passed with its transfer and that the transfer must have taken place under an illegal agreement. Dumas lost ownership of his funds and the transfer took place illegally due to the fraud. 
Given that Whitehead's estate is now insolvent, Fox ("Defective Payments of Incorporeal Money in South African and English Law" 2009 Journal of SA Law 638 650) submits that an unjustified enrichment claim would rank pari passu alongside all the other claims of the beneficiary's unsecured creditors if he or she were insolvent. Whether this would be the position or whether Duma's claim will have priority does not affect the fact that the unjustified enrichment action is the most plausible remedy at Dumas's disposal.

\section{Conclusion}

As has been noted in this case, it is possible that the law may fail to afford protection to law-abiding citizens which it rightly ought to protect. Sometimes, as the case of Dumas indicates, this may be as a result of mere misapplication of the law by the courts. The judgment of Dumas has set a wrong precedent that will be binding on all the lower courts. Thus many innocent persons who may find themselves in a similar situation as Dumas may be left exposed by the law. However, the ultimate responsibility rests on individuals who engage in a financial transactions for whatever reason, to ensure that they are certain about what they are entering into or what they are dealing with prior to transferring huge amounts of money to strangers' bank accounts (or even to acquaintances). It is also essential that everyone understands the principles underlying banking transactions, particularly that once money is transferred from one bank account to another, the transferee bank assumes ownership of the money. Any personal rights that the transferor may have in respect of such money are terminated. This would leave the transferor with no power over the processes that follow in the handling of that money such that, if the judgment of Dumas is anything to go by, where the transferor is misled and voluntarily enters into a fictitious investment transaction, s/he will lose his/her money. In this case, on several occasions the court correctly set out the relevant law principles. For example it noted that:

"Once ownership passes to the bank it immediately incurs the obligation to account to its customer. But a customer does not always acquire an enforceable personal right to the credit in his account merely by virtue of the deposit. A bank is entitled to reverse a credit in the account-holder's bank account if it transpires that the account had been credited in error, that the customer had acquired the money by fraud or theft, that the drawer's signature on a cheque had been forged, or that the bank notes deposited in the account were forgeries"(par [14]).

Nonetheless, the SCA still reached a conclusion contrary to these principles, despite correct encapsulation of the law. Observably, the error was due to its failure to apply the law (correctly). Had the law been applied correctly, neither Whitehead nor the trustees of his insolvent estate would have had any legitimate claim to the money fraudulently transferred into Whitehead's bank account. The money had been deposited into Whitehead's account as a result of unlawful conduct - fraud and misrepresentation. This in turn vitiated the creation of a personal right in favour of Whitehead such that he had no claim of the money from the bank. Hence, the Absa bank was obliged to reverse payment to Dumas's bank, FNB. 
Moreover, like many of us, Dumas had been ignorant about the consequences of bank transfers. He had no idea that transferring his money would result in the transfer of ownership from FNB to Absa, the receiving bank. In turn, his personal right to the money was terminated, leaving him with no control over the money. Instead, Dumas laboured under the impression the money would remain his property until a deal had been concluded a few days later in the meeting (which never took place) between Whitehead and Dumas, as agreed between him and Whitehead's agency (par [4]). The case serves as a reminder that members of the public should be conversant with the ramifications of their purported financial transactions, including the legal ramifications thereof. Whilst failure to take the necessary steps to satisfy oneself of the legitimacy of an investment scheme does not necessarily constitute negligence that would forfeit the legal protection afforded to a victim of fraud, it does help to avoid situations such as the one in which Dumas found himself, as well as avoid to lengthy and costly litigation. In particular, the case shows the danger of hastily concluding investment trans-actions that promise high investment returns. Until the law is set straight in this area of law by another court, individuals all bear the responsibility to safeguard their interests in financial dealings. Even then, the need for vigilance will remain as the availability of legal recourse is not an express ticket to be negligent in financial dealings. Although failure to discharge this responsibility of being wary does not stop the law from protecting the victim of fraud, the primary responsibility lies with the individual, hence the need for vigilance.

Musa Kika

Third year LLB student University of KwaZulu-Natal, Durban

Michael Celumusa Buthelezi University of KwaZulu-Natal, Durban 